\title{
The Utilization of Tween 80 as Carbon Source by Pseudomonas
}

\author{
By T. G. B. HOWE AND JUDITH M. WARD \\ Department of Bacteriology, The Medical School, Bristol BS8 ITD
}

(Received 20 August 1975)

\section{INTRODUCTION}

Members of the genus Pseudomonas are unusual among bacteria in their ability to utilize a wide range of exogenous substrates, and some strains harbour plasmids capable of conjugal transfer to several different genera (Clarke \& Richmond, 1975). As part of a study of the transfer of genes for catabolic enzymes from Pseudomonas to other hosts, we have looked for the capacity to degrade the detergent Tween 80 (polyoxyethylene sorbitan mono-oleate) in a number of strains. Sierra (1957) reported the formation of calcium oleate from Tween 80 in zones surrounding bacterial growth on solid medium, and Tween 80-hydrolysing enzymes have been prepared from pancreatic extracts (Hall, 196I) and from rat adipose tissue (Wallach, Ko \& Marshall, 1962).

\section{METHODS}

Strains. Pseudomonas aeruginosa PAO and PAT (Holloway, 1955) were obtained from Professor B. W. Holloway, Monash University, Australia. Pseudomonas fluorescens 950, 8248 and 8249, and Ps. putida 9034, were obtained from the laboratory culture collection.

Culture media. Cultures were grown on nutrient medium (Difco heart infusion agar) and minimal medium (Difco Bacto agar) supplemented with Tween 80 (Koch-Light; $1 \%$, v/v) and $\mathrm{CaCl}_{2}(0.01 \%, \mathrm{w} / \mathrm{v})$ where appropriate.

Mutagenesis. Pseudomonas aeruginosa PAO and PAT were screened for mutants using the mutagen $N$-methyl- $N^{\prime}$-nitro- $N$-nitrosoguanidine (Koch-Light; Adelberg, Mandel \& Chen, I965), on medium supplemented with Tween $80+\mathrm{CaCl}_{2}$ on which colonies of the parent strain are surrounded by a zone of opacity. Colonies lacking the characteristic zone were selected and purified.

\section{RESULTS AND DISCUSSION}

Two mutants of $P$ s. aeruginosa with reduced or absent Tween 80-degrading ability were isolated; one mutant (PATI 2275-I) showed a much reduced zone and acquired an additional auxotrophic requirement, and a second (PAOI 594-I) showed no detectable zone and also lost the ability to grow on minimal medium with Tween 80 as carbon source. The phenotype of PAOI594-I was used in direct selection for re-acquisition of the ability to utilize Tween 80 on mating with Tween 80-hydrolysing donor strains. Strain PAOI 594-I recovered the ability to grow on Tween 80-supplemented minimal medium when mated with PAO $\left(\mathrm{FP}^{+}{ }^{+}\right.$) (frequencies : $2.6 \times \mathrm{IO}^{-6}$ to $2.8 \times \mathrm{IO}^{-6} /$ donor cell) and when mated with PAO $\left(\mathrm{RPI}^{+}\right)$(frequencies: $0.1 \times 10^{-8}$ to $1.2 \times 10^{-7} /$ donor cell). Recombinants were scored after $24 \mathrm{~h}$; occasional revertants (about I per plate) were seen on control plates, and confirmatory tests showed that these colonies possessed the markers characteristic of the recipient parent. Escherichia coli $\mathrm{KI} 2 \mathrm{did}$ not show any opacity on Tween 80-supplemented nutrient medium, nor did it grow on Tween 80-supplemented minimal medium; we are currently attempting to transfer the activity from $\mathrm{PAO}\left(\mathrm{RPI}^{+}\right)$to $E$. coli. 
In addition to finding this activity in all strains of $P$ s. aeruginosa tested, we have also detected it in three strains of Ps. fluorescens $(950,8248$ and 8249) and, at a low level, in Ps. putida 9034. Strain PAOI594-I retains the ability to digest the triglyceride tributyrin (aliesterase: Sierra, 1957), an activity absent from $E$. coli, and we therefore tentatively assume that this property is determined by a different enzyme from that which hydrolyses Tween 80 The rat adipose enzyme described by Wallach et al. (1962), however, hydrolysed both Tween 80 and tributyrin. Lipases are currently classified among the hydrolases (Desnuelle, 1972) but are considered to act very slowly, if at all, on water-soluble substrates such as Tween 80 (Wills, 1965). According to this definition the activity we have described is not a true lipase but is likely to be an esterase. The further investigation of such enzymes is likely. to be important in view of the need for controlling biological degradation of detergents and environmental pollutants.

This work was supported by a grant from the Ministry of Defence Procurement Executive, and in part by a grant to Professor M. H. Richmond from the Medical Research Council for molecular and epidemiological studies on $\mathbf{R}$ factors.

\section{REFERENCES}

Adelberg, E. A., Mandel, M. \& Chen, G. C. C. (1965). Optimal conditions for mutagenesis by $N$-methyl$N^{\prime}$-nitro- $N$-nitrosoguanidine in Escherichia coli XI 2. Biochemical and Biophysical Research Communications $18,788-795$.

Clarke, P. H. \& Richmond, M. H. (1975). Evolutionary prospects for Pseudomonas species. In Genetics and Biochemistry of Pseudomonas, pp. 341-358. London: Wiley.

Desnuelle, P. (1972). The lipases. In The Enzymes, vol. 7, pp. 575-6i6. Edited by P. D. Boyer. New York: Academic Press.

Hall, D. A. (196I). The characterization of a new lipolytic enzyme in pancreatic extracts. Biochemical Journal 78, 49I-499.

Holloway, B. W. (1955). Genetic recombination in Pseudomonas aeruginosa. Journal of General Microbiology 13, 572-581.

SIERRA, G. (1957). A simple method for the detection of lipolytic activity of micro-organisms and some observations on the influence of the contact between cells and fatty substrates. Antonie vanLeeuwenhoek 23, I5-22.

Wallach, D. P., Ko, H. \& Marshall, N. B. (1962). Purification and properties of a Tween-hydrolyzing enzyme from rat adipose tissue. Biochimica et biophysica acta 59, 690-699.

WiLls, E. D. (1965). Lipases. Advances in Lipid Reseurch 3, 197-240. 